\title{
Shadow Banking In The United States And China :What Are The Risks?
}

Marshall D. Nickles, Ed.D., Pepperdine University, Los Angeles, California, USA

Jeffrey Schieberl, J.D., Pepperdine University, Los Angeles, California, USA

\begin{abstract}
This paper addresses the concern the authors have regarding the speculative nature of shadow banking in the United States and China in particular. There appears to be ample evidence that shadow banking in the United States was a major contributor to the speculation that led up to the 2008 - 2010 financial crisis. The same type of speculation was also responsible for the U.S. stock market collapse of 1929. During the 1930's the Glass-Steagall Act was enacted to address the potential conflict of interest between commercial and investment banking activities. This Act was altered in the 1990's by a majority vote in Congress. Some believe that this partial gutting of the Glass-Steagall Act contributed to America's unregulated shadow banking activities and real estate speculation that followed. At present China's shadow banking sector is following a similar speculative path that the United States did about seven years ago. A difference is that China's commercial and shadow banking systems are absent of many of the mechanisms that allowed the U.S. to regulate its way out of America's financial crisis. This paper compares past and current U.S. and Chinese shadow banking activities and draws conclusions relative to certain sectors in the Chinese economy that are overheated and primed for economic difficulties that could have global implications.
\end{abstract}

Keywords: Shadow Banking; China’s Real Estate Bubble; Mortgage Lending Oversight

\section{INTRODUCTION}

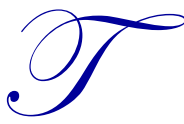

he Shadow banking system is a mystery to some because much of what is done in that universe is either not understood or not reported to regulatory agencies. Ben Bernanke, the past chair of the Federal Reserve, defined shadow banking as follows:

"Shadow banking, as usually defined, comprises a diverse set of institutions and markets that,collectively, carry out traditional banking functions but does so outside, or in ways only loosely linked to the traditional system of regulated depository institutions. Examples of important components of the shadow banking system include asset banked commercial paper, money market mutual funds, markets for repurchase agreements (repos), investment banks, and mortgage companies. The activity of some of the above components is unregulated and is of concern in China today. This concern was also present in the United States prior to financial crisis that began in 2007" \{Bernanke, 2012\}.

This paper will attempt to provide insight into the following: First, examine some of the economic and legislative events that took place in the U.S. prior to the $2008-2010$ financial crises. Second, compare some of the above events to what is happening in China today. Third, examine some of the vulnerabilities in China's financial system within its shadow banking sector. Finally, draw some conclusions and implications to the global economy.

\section{SHADOW BANKING IN THE UNITED STATES}

Timothy Geithner, the past U.S. treasury secretary, directly linked the 2008 - 2010 American banking problems on a crisis within some of the components of shadow banking described above by Bernanke. Geithner 
continued by saying that the "off-balance sheet" activity (particularly the mortgage industry) were outside regulatory controls of traditional banking institutions \{Geithner, 2008\}.

The Glass-Steagall Act (passed during the 1930's U.S. depression) separated commercial banks from investment banks. This Act was modified during the Clinton administration in the 1990's with bipartisan Congressional support. By 2007, investment banks then linked to commercial banks became a "hotbed" for shadow banking activity with much less regulatory control than when the Glass-Steagall Act was fully operational. This ultimately gave rise to Bear Sterns and Merrill Lynch being acquired by bank holding companies and the collapse of Lehman Brothers ending in bankruptcy. The Lehman Brothers collapse was not isolated and created collateral damage. This became evident as they had to rapidly liquidate their longer term assets on the open market as prices were rapidly falling. The declining real estate market affected other financial institutions that needed to raise money. More specifically, investment banks had become dependent on short term financing, but because of their financial structure needed to access their funds through long term capital markets. The problem was that the value of longer term assets like real estate was beginning to rapidly fall \{Jones, 2013\}.

Before the 2008-2010 financial meltdown, the shadow banking system had overtaken the regulated banking system in terms of lending money to consumers for homes, autos, and student loans \{Hall, 2009\}. This created systemic risk within the entire financial system because unregulated shadow banks were connected to traditional banks through various credit chains \{Cowen, 2012\}. Shadow banks did not have to maintain financial reserves or deposit insurance which further exposed their risk to the general economy. Shadow banks are considered to be direct financial institutions. The business activity of these banks is speculative since their long term investments need to continuously rise, which is not possible. The above was true for the United States prior to its financial crisis; however the mechanism or activities of shadow banking are not as clear in China as in the West. What is clear is that much of the shadow banking (banks and trust companies) activity in China is done by selling direct investments and trust instruments to wealthy individual investors. This process passes the financial risk to individual not the banking system that is selling the products. These Chinese investment instruments are not guaranteed and they also bypass any traditional banking and real estate regulations. The above problem was at the core of the U.S. financial problems (2008 - 2010) and is currently the concern in China \{RIETI, 2013\}.

The recent world-wide great recession has also been directly linked to shadow banking behavior. Paul Krugman, an economist, who stated the following in the aftermath of the U.S. crises:

“. . as the shadow banking system expanded to rival or even surpass conventional banking in importance, politicians and government officials should have realized that they were re-creating the kind of financial vulnerability that made the Great Depression possible - they should have responded by extending regulations and the financial safely net to cover these new institutions. Influential figures should have proclaimed a simple rule: anything that does what a bank does, anything that has to be resented in a crisis the way banks are, should be regulated like a bank" \{Krugman, 2009\}.

The above quote by Krugman could also have been applied to the credit bubble in the latter 1920's in the U.S. The American government attempted to partly address the domestic economic depression of the 1930's by passing the Glass-Steagall Act. This legislation had become best known for requiring the separation of commercial banking activity from investment banking \{Reinicke, 1995\}.

In November, 1999, President Bill Clinton signed the Gramm-Leach Act that repealed some provisions of the Glass Steagall Act. This removed the separation that previously existed between commercial banks that financed the underwriting process and investment banks which issued securities. Since the recent global Great Recession, many believe that the partial gutting of the Glass-Steagall Act contributed to the U.S. financial crisis \{Mannuel, 2011 \}. By 2010, Congress passed the Dodd-Frank Act. This legislation attempted to address shadow banking by allowing the Federal Reserve to regulate most of the financial institutions that were directly or indirectly involved in the financial meltdown. To date the full implementation of the Dodd-Frank Act has not been completed. 


\section{SHADOW BANKING IN CHINA}

The notion that economists can focus on individual countries or regions and derive meaningful forecasts has become nearly impossible without considering the macro environment. Globalization has made most of the developed and developing nations dependent on each other. An example was Thailand in 1998 with their financial problems that spread financial "contagion" to South Korea, South America, Russia, and ultimately the United States with the near collapse of Long Term Capital Management (LTCM), a global hedge fund based in New York. Shanker Satyanath makes the point that when banks in South East Asia disclosed unreliable information to the public, especially when certain counties were near financial collapse (as was the case with Thailand) bank runs can become very costly, risky, and "contagious" \{Satyanath, 1999\}.

China is no exception when it comes to the vagaries of globalization. Paul Krugman believes that China's economy contains many of the same signs of speculation that the U.S. did in late 2007. More specifically he states that: "China's thirty years of incredible growth has reached its limits . . the only question is just how bad the crash will be" \{Krugman, 2013\}. In the late 1990's, China saw its government attempt to grow their economy by converting small town land into industrial projects. This effort was not as successful as expected and was replaced with a strategy to build "new cities' at urban fringes. This construction contained commercial as well as residential structures. Success was marginal in that property values rose but the vacancy rate was very high $\{$ Hsing, 2010\}. Simulative economic growth was also necessary in an effort to employ the massive amount of Chinese labor. This necessitated the raising of large amounts of funding from traditional and non-traditional (shadow banking) sources.

Additional research argues that shadow banking has played a much larger role in China's economic growth in the smaller villages, towns, and suburban areas where GDP growth has been most robust and where data transparency can be less creditable \{Allen, etc., 2008\}. Further estimates that China's 2012 GDP growth came from suburban areas was reported by Citi Bank. The bank's research believed the figure to be 54 percent, while Moody's estimate was at 55 percent $\{$ Accelus, 2014\}.

According to Thomson Reuters, the Chinese housing market has increased the liquidity risk in the Chinese economy as a whole. Reuters lists 5 risk factors (including the housing market) that are growing concerns for China's financial markets. Of even more concern is that shadow banking activity is exacerbating these risks that are quoted below by Paul Kurtz \{Kurtz, 2013\}:

1. Housing prices - Reuters research states, “. . . given Chinese constructors' foremost aim of attracting investment, rather that catering to residential demand, the problem of vacant apartments in China is much more severe than it was in the U.S. The media claims that there are approximately 64.6 million empty apartments in China. This is enough to house 200 million people".

2. Interest and inflation rates - While interest rates have remained relatively low because of tempered inflation, this could change as world economies improve. If interest rates were to begin to rise, it would decrease the flow of funds into the shadow banking sector. This potential illiquidity would be very risky to several parts of the Chinese economy, especially the Chinese real estate market.

3. Capital flow - As China moves toward opening its capital account, it could lead to a large outflow of currency from China to other parts of the world with higher rates. This could also promote illiquidity.

4. Repro Rate - In June, 2013, there was an increase in traditional Chinese banks' financing cost and thus increased mortgage rates. This put downside pressure on real estate prices.

5. Required Reserve Ratio - As of mid-2014, the Chinese reserve ratio (amount of traditional state supported bank deposits that can't be loaned out) was much higher than in the U.S. or Europe. This made shadow banking (off the traditional balance sheet) activity in China that much more attractive.

While the above denotes some of the more obvious immediate concerns that are facing the Chinese economy, there are other less obvious troubling factors. For example, any last decade tightening of monetary policy in China has been directed toward the traditional state owned banks, and the effects should have been typically felt by the broad economy and specifically money and capital markets as they are in the West; and this was the case when China implemented its quantitative easing policy in 2008. The results were an approximate $\$ 580$ billion (US) dollar stimulus that fed the impressive economic growth rates in China since the global recession. However, the 
stimulus helped the state sector but not necessarily the "free market" parts of China's fringes - where the core growth is \{Coase, 2012\}. This led to a shortage of funds for the broader economy by the end of 2010 as Chinese monetary policy was reversed and monetary policy was tightened \{RIETI, 2013\}. This more restrictive monetary policy and the chain of events that followed prompted the traditional state owned banks to skirt the more restrictive regulations imposed on the banking system by engaging in more shadow banking activity themselves.

By 2013 it was estimated that approximately 36 percent of China's GDP was related to shadow banking. This meant that transparency within above banking activity was difficult at best and thus made financial risk evaluation near impossible \{RIETI, 2013\}. J. Elster argues, that a banking system without traditional banking channels that are enforced by regulators and allows for financial information to potently flow through the system without informing the public is highly risky. He further argues that transparency the above allows for the potential early detection of any problems and attempts to resolve them before they lead to a crisis. This, he believes, cannot be achieved within a shadow banking system \{Elster, 2000\}.

\section{CHINA'S ATTEMPT TO REFORM}

It is apparent that China has been moving toward embracing a market style economy at the margin and slowly dismantling the old communist ideology. This is a major change and requires the adoption of some of the characteristics of free market capitalism found in the West. The above means that China should, at a minimum, disclose more information regarding business and banking activities than it has been doing in the past in order to continue with its post-industrialization. While China enjoys a favorable balance of international trade with most of the world, its economy is not competitive on all fronts. An obvious example of this is the fact that China's businesses compete mainly on price. This has been the case because of its global advantage with cheap labor and low production costs. The Chinese government has recognized this deficit and has been trying to correct their general lack of new and innovative product output. Ronald Coase and N. Wang argue the following relative to China's limited ability in the area of innovative product production. They argue the following: "Short on innovation and lacking their own distinctive products, many Chinese firms depend on ordered manufacturing - taking orders from overseas markets and selling them under foreign brand names" \{Coase and Wang, 2012\}. In order to correct the above, considerable business cultural reforms are likely since product innovation was not a part of a traditional communist economy. This transformation into the global mainstream of international competition with the West won't come cheaply. Whether the above effort will entail tapping further into the unregulated shadow banking activity in China remains to be seen?

\section{CHINA'S RELIANCE ON SHADOW BANKING}

During 2013, China's State Council drafted document No. 107 that attempted to address separate regulations for state banks and some shadow banking activities. However, the description of how the oversight would be enforced was vague. More specifically, the document stated that different types of shadow banking activities would be viewed on a "one by one" basis and would be managed by "relevant institutions". The Council declared shadow banking as playing an active and "inevitable" role in financing the development of the Chinese economy. Although the Chinese government has attempted to address shadow banking activity, the reality is that as Beijing has allowed nontraditional financial institutions to lend to local municipalities these municipalities have become heavily in debt. A Wall Street Journal article reported on the recent massive built up in China's domestic debt:

\footnotetext{
"Since 2008, domestic Chinese debt has ballooned to $216 \%$ of gross national product from $128 \%$, and could climb to $271 \%$ by 2017 if not corrected, according to Fitch Ratings. Overall $43 \%$ of local governments', 17.9\% trillion yuan (\$2.93 trillion), debt as of the end of June 2013 came from nonbank sources, according to a National Audit Office report released last week. Shadow banking institutions, including trust companies, securities firms, insurance companies, and leasing companies that accounted for $11 \%$ of the local governments' debt. The rest of the nonbank debt is from bonds, individuals, and loan guarantees. A crackdown on shadow banking could threaten the financial viability of China's local governments and their ability to repay their loans" \{Wei, etc., 2013\}.
} 


\section{CONCLUSION AND IMPICATIONS}

It appears that the growth of unregulated shadow banking proved to be a mistake in the West and can be true in China as well. The Glass Steagall Act was originally enacted in the United States in an effort to help ensure financial stability by preventing potential conflict of interest between the regulated commercial banks and higher risk taking investment banks. The modification of the Glass Steagall Act during the 1990's could have led to the major financial crisis not only in the U.S. but throughout many parts of the free world. Based on our research, the Chinese economy appears to be on a similar trajectory as America was prior to the crash in 2008 and beyond. Similar repercussions in China could also have a major impact on the banking and capital markets throughout the world. It also seems that much of the dynamic economic growth in China has been from efforts of private entrepreneurship, which was illegal prior to China's economic reform. Further, it appears that the traditional state banks in China have not been that experienced in providing loans and access to the capital markets that are necessary for private sector type businesses. Hence, in an effort to service China's rapid growth policies, the emergence of shadow banking expanded to the point of becoming not only useful to entrepreneurs but quite necessary for the continued growth and prosperity of China's overall economy, \{Coase and Wang, 2012\}. Evidence suggests that there is in fact an economic bubble in the making that could not only affect China but its international trading partners as well. This threat is enhanced in our opinion, because the Chinese government has not had experience in dealing with such a crisis nor does it have the banking structure as the U.S. did in "controlling" its recent 2008 - 2010 domestic and global financial crisis. Finally, we believe that it is necessary for the Chinese government to learn from the recent financial experience of the West and take appropriate action to not duplicate a similar problem.

\section{AUTHORS INFORMATION}

Marshall Nickles, Ed.D., Pepperdine University, Economics Department, Los Angeles, California, USA. E-mail: marshall.nickles@pepperdine.edu. Marshall Nickles is a professor of economics at Pepperdine University's Graziadio School of Business and Management.

Jeffrey Schieberl, J.D., Pepperdine University, Legal Studies Department, Los Angeles, California, USA. EMail: jeffrey.schieberl@pepperdine.edu. Jeffrey Schieberl is a faculty member at Pepperdine University's Graziadio $\underline{\text { School of Business and Management. }}$

\section{REFERENCES}

Accelus.thomsonreuters.com, January, 2014., (http://ihome.ust.hk/-su_mbisa/. P 4.

Allen, Qian and Quian, M. (2008). China's Financial System: Past, Present, and future, in Brandt, L. and Rawski, T. edition of "China's Great Economic Transformation", Cambridge, Cambridge University Press, PP 506568.

Bernanke, Ben, Reflections on the Crisis and the Policy Response, (http"//www. Federalreserve.gov./newsevents/speech/Bernanke 20120413a.html), April, 2012.

Coase, Ronald and Wang, Ning (2012). How China Became Capitalistic, Basingstoke: Palgrave Macmillan. (www.cato.org/policy-report/january/february-2013.

Cowen,Tyler, The Age of the Shadow Bank Plan,

(http://www.nytimes.com/2012/25business/the-bank-run-updated.html). The New York Times. Mytimes.com.2012-324.

Dave Manuel.com, Oct. 11, 2011 (1:30 pm EST).

Elster, J. (2000). Ulysses Unbound Studies in Rationality, Precommitment, and Constraints, Cambridge: Cambridge University Press. (www.jstor.org/stable/30937224.

Geithner, Timothy, "Reducing Systemic Risk in a Dynamic Financial System, (http://www.newsevents/speeches/2008/tfg080609.html),speech transcript. Delivered 2008-6-

Hall, Robert E. and Liberman, Marc (2009). Economics: Principles and Applications (http://booksgoggle.com/books

Jones, Huw, "Shadow Banks Face 2015 deadline to comply with first global rules", (http:'//www. Reuters.com/article/2013/08/29/usg20shadowbanking-rules-idUSBRE97SOTX20130829.Dec. 2008. 
Krugman, Paul, The Return of Depression Economics and the Crisis of 2008, W. W. Norton and Company, 2009. (http://www.nytimes.com/2013/.

Krugman, Paul, (2013). Hitting China's Wall, July 18, 2013, p538 Comments.

Kurtz, Walter (2013), "Country Risk - China's Economy: New Warning Signs”, Pragmatic Capitalism, June 18.

Reinicke 1995, pp. 104-105. Greenspan and 12-15, Federal Reserve Bulletin, 1998.

RIETI (Research Institute of Economy, Trade and Industry). 2013. "China in Transition: Shadow Banking in China: Current Situation and Challenges", (http://www.rietic.go.jp/en/china/13080601.html?

Satyanath, S. (1999). Accommodating Imprudence: The Political Economy of Information in the Asian Banking Crisis, Unpublished, Department of Political Science, Columbia University.

Wei, L. Davis, B. Hong, S,

(http://online.wsj.com/news/articles/SB1000142405270022304887104579303732528192434).1/6/14,7:30p mET. 